\title{
NOTES ON THE REGENT ADVANCE AND RETREAT OF SEFSTRÖMBREEN IN EKMANFJORDEN, VESTSPITSBERGEN
}

\author{
By D. L. Dineley \\ (Department of Geology, University of Ottawa) \\ and $\mathrm{R}$. S. WATERS \\ (Department of Geography, Exeter University)
}

\begin{abstract}
These notes are based on observations made in 1958 while the writers were members of the Birmingham and Exeter Universities Spitsbergen Expedition. The position of the ice front in 1958 is compared with that recorded on five previous occasions between 1882 and 1936 . A rapid $6 \mathrm{~km}$. advance at the end of the nineteenth century has been followed by a slower but equally extensive retreat. A revision of the limit of maximum advance is based on geomorphological evidence. Reasons are suggested for the relatively small changes in the outline of the ice front since 1927 , and the effects of spells of moderately high atmospheric pressure are noted.
\end{abstract}

RÉsumÉ. Ces notes sont basées sur des observations faites en r 958 pendant la "Birmingham and Exeter Universities Spitsbergen Expedition". On a comparé la limite atteinte par le front de glace en 1958 avec celles observées cans cinq occasions précédentes entre 1882 et 1936 . Une avance rapide de $6 \mathrm{~km}$ s'est produite à la fin du dix-neuvième siècle; par la suite une régression tout aussi considérable s'est effectuée, mais à une vitesse moindre. On a revisé l'estimation de la limite maxima atteinte en s'appuyant sur les indices géomorphologiques. On suggère les facteurs susceptibles d'expliquer les changements relativement peu importants survenus dans le tracé du front de glace depuis 1927; on discute les effets provoqués par les
courtes périodes de pression atmosphérique assez élevée.

Zusammenfassunc. Jiese Aufzeichnungen beruhen auf Beobachtungen, die im Jahre I95 gemacht wurden, als die Verfasser Teilnehmer der „Birmingham and Exeter Universities Spitsbergen Expedition“" waren. Die Eisfrontlage im Jahre 1958 wird mit der verglichen, die bei fünf früheren Anlässen zwischen 1882 und 1936 festgestellt worden war. Auf einen schnellen $6 \mathrm{~km}$ Vorschub am Ende des I9. Jahrhunderts folgte ein langsamer aber ebenso w x tensiver Rückgang. Eine Revision der Grenze maximalen Vorschubs stützt sich auf geomorphologische Nachweise. Es werden Gründe für die verhältnismässig kleinen Veränderungen im Umriss der Eisfront seit 1927 vorgeschlagen, und die Auswirkungen von Perioden mässig hohen atmo-
sphärischen Druckes sind notiert.

RECENT changes in the length of Sefströmbreen at the head of Ekmanfjorden, Vestspitsbergen, are well documented by the combined record of six successive observations of its terminus made between 1882 and $1958 .^{I}$ This record (Figs. I and 2) shows that an advance of about $6 \mathrm{~km}$. between $\mathrm{I} 882$ and 1896 which brought the glacier snout from a position well within the north-western inlet of Ekmanfjorden across more than two-thirds of the fjord to Coraholmen and Flintholmen was succeeded by an equally extensive but much slower retreat, the rate of which has progressively declined. Thus in $195^{8}$ the ice front lay very close to its $\mathrm{I} 882$ position.

In his account of the early fluctuations, de Geer ${ }^{2}$ suggested that the farthest advance of the ice front had occurred between 1882 and 1896 , at which time Flintholmen had been completely overwhelmed (Fig. I). The mass of red, shelly moraine occupying the northern half of the island he regarded as representing the 1896 halt in a recession which had already set in. There is, however, no evidence that the southern part of Flintholmen was covered by the late nineteenth century ice advance. Its southerly dipping cherts carry an undisturbed series of raised beach shingle ridges identical with those on the eastern half of Coraholmen and, across the fjord, on Blomesletta. An account of these raised beaches is to be published elsewhere, but it may be noted that coast sections show the Sefström moraine overlying the chert shingle. In every respect, therefore, Flintholmen resembles Cora and its mass of moraine represents the limit of the I 882-96 advance. Its complete glacierization, like that of Blomesletta, antedates the deposition of the raised beach ridges.

According to De Geer, the ice front remained across Flintholmen until I9o8, by which time the central part of the ice lobe had broken back some $2 \mathrm{~km}$., and a detached portion of 
dead ice lay grounded against the western part of Coraholmen. Lamplugh, in his detailed account of the moraine on Cora, noted that by August 1910, "the waterway west of Cora Island had grown broader; but the detached remnant of the glacier, though greatly diminished by melting and undermining, still clung to the island". 3

The next 20 years witnessed the disappearance of ice from both islands and a further

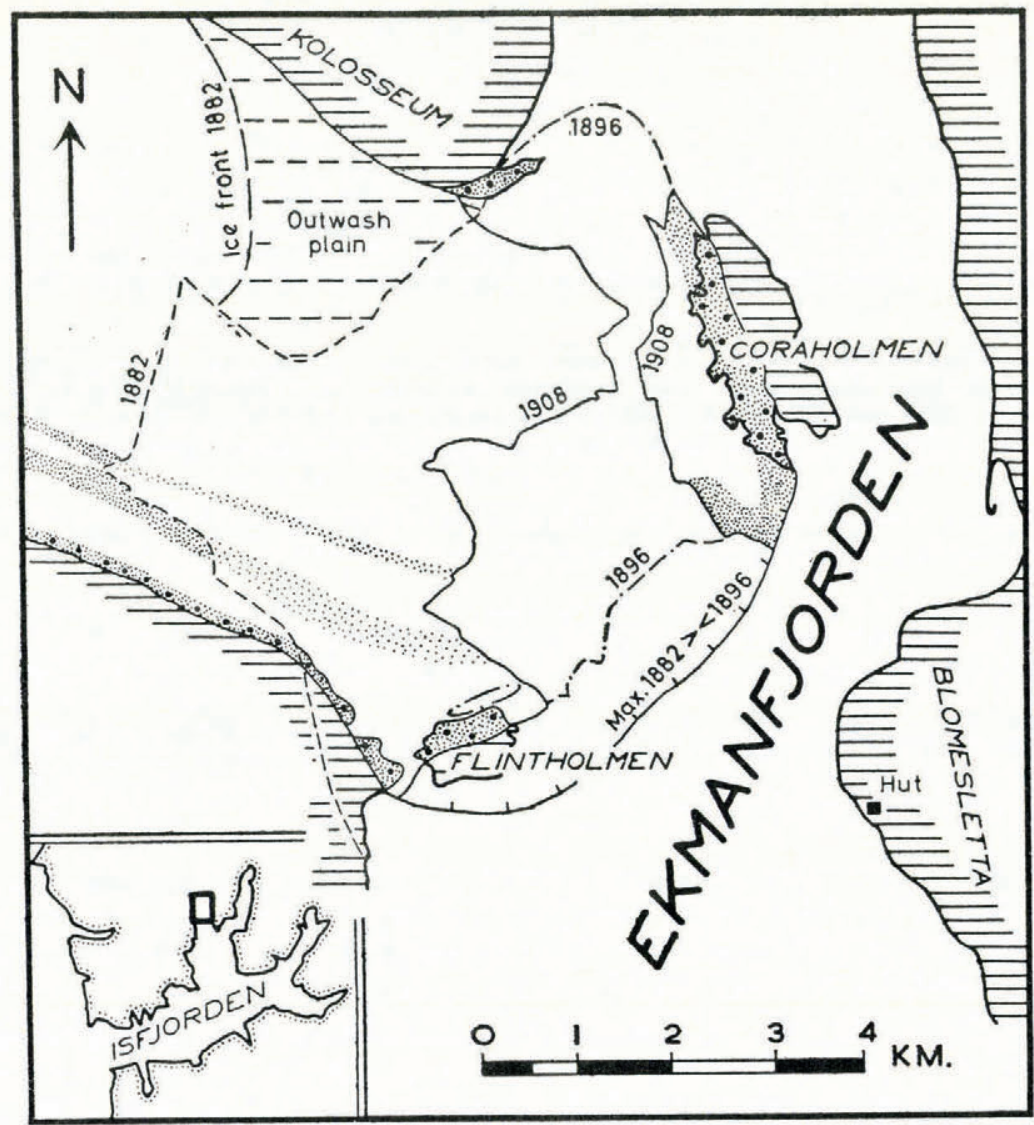

Fig. I. Successive fronts of Sefströmbreen between 1882 and 1908 (based on de Geer, Lamplugh)

decrease of about $2 \mathrm{~km}$. in the length of the glacier. By $1927^{4}$ (Fig. 2) the ice front lay along the outer limit, and south-westwards, of the triangular area occupied by an outwash plain in 1882 .

During the last 30 years the ice margin has become increasingly irregular. It would appear that its stationary north-eastern half is underlain at no great depth by the rock shore of the fjord, which is, however, concealed by a beach of moraine. Since 1927 progressive thinning of this part of the glacier by down-melting and its gradual blanketing by ablation moraine has been accompanied by the continued retreat of the south-western portion of the ice front which still reaches tidal water. Calving ice cliffs possibly up to $75 \mathrm{~m}$. high, bordered a deep embayment in this latter part of the ice front in 1958. The greater part of the glacier's melt water appears now to enter the fjord below low water mark from subglacial or englacial 
channels under these ice cliffs and the lateral surface streams are comparatively small for a glacier of this size. Very low tides expose a small island patch of moraine about $150 \mathrm{~m}$. in front of the ice cliffs and this, perhaps owing its origin to deposition from a subglacial or englacial channel, seems to indicate that the depth of water below the present ice cliffs cannot be very great. The crevasse pattern on the glacier surface, however, suggests that

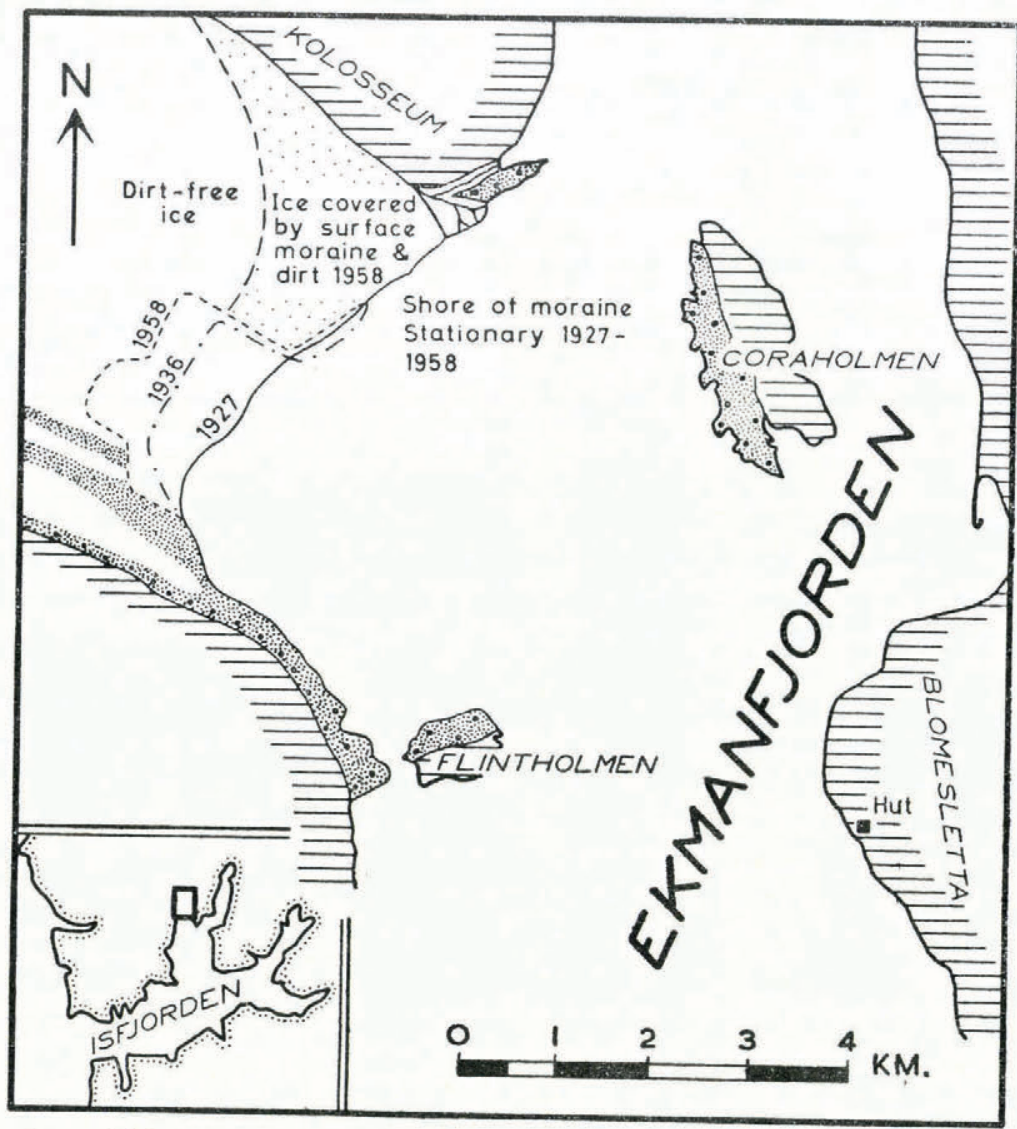

Fig. 2. Successive fronts of Sefströmbreen between 1927 and $195^{8}$ (based in part on Gripp and on an unpublished map made
available by Norsk Polarinstitutt) calving will continue to reduce the glacier for a very considerable distance behind the present
ice front.

In spite of the general similarity between the positions and outlines of the ice front in 1882 and 1958 it is suggested that the observed differences in the two patterns are significant. In $195^{8}$ when the south-western part of the front was retreating rapidly, ice-cored moraine on the west of Kolosseum occupied the area shown as outwash plain on the map of 1882 , and the limit of dirt-free ice coincided with the position of the r882 ice front. Thus it would appear that the 1882 map represents a dynamic situation quite different from that which existed in $195^{8}$. It is suggested that at the time of the first observation the glacier was already in a state of active growth, having advanced down its valley from a position somewhat inland 
of the site of the present ice cliffs. The deposits of the outwash plain were perhaps dispersed by the advance of the ice and by marine action. Thus the spectacular advance at the end of the nineteenth century followed a period during which the glacier was even less extensive than it is at present.

This interpretation of the behaviour of Sefströmbreen during the last 76 years confirms the observations of Lamplugh who noted that many Spitsbergen glaciers "are subject to spasmodic fits of rapid and tumultuous advance, alternating with longer intervals of retreat and ablation during which they become relatively stagnant".5

De Geer suggested that these fluctuations are "due to the inadequacy of the annual rainfall to maintain a constant flow in cases where the gradient of the glacier is gentle, so that the accumulated load of several years may be required to overcome the rigidity of the ice; but when the limit is overpassed a phase of active movement is started and may go on vigorously until the extra load is fully discharged and the stage of quiescence is again reached". 6

A similar hypothesis appealed to Ahlmann 7 when considering a number of such cases of fluctuation. More recent work in this field suggests that the thickening of the accumulation lavers in the névé increases both the surface gradient and the mass of the glacier. The resulting increase in the downhill component of gravity gives rise to stresses in the ice along the bed of the glacier substantially in excess of the yicld stress of ice, and this causes a forward surge. Dr. Glen ${ }^{8}$ has demonstrated that the strain rate of ice at $0^{\circ} \mathrm{C}$. increases approximately as the fourth power of the stress, so that relatively small increments of stress within a glacier can cause very rapid advances.

The rapid variations in the length of Sefströmbreen are thus to be explained ultimately in terms of those climatic fluctuations which control its regimen. Nevertheless, our observations in $195^{8}$ suggest that the rate of retreat of a diminishing tidewater glacier may be significantly affected by particular meteorological conditions.

The months of July and August in Ekmanfjorden were characterized by two prolonged spells of moderately high barometric pressure. Over a period of 22 days ( 7 July to 7 August) the mean pressure was I, $008 \mathrm{mb}$., with daily readings ranging between $\mathrm{I}$, 000 and $\mathrm{I}, 0 \mathrm{I} 4 \mathrm{mb}$. On 8 August the pressure fell to $994 \mathrm{mb}$., and on the $9^{\text {th }}$ and roth it stood at 995 and $994 \mathrm{mb}$. respectively. Thereafter, pressure increased once more, and for the second spell, from i i to 24. August, the mean was I,O I $\mathrm{mb}$. and the range of daily readings $\mathrm{I}, 000$ to $\mathrm{I}, \mathrm{OI} 5 \mathrm{mb}$.

Although the average pressures for the two spells were by no means abnormal it is suggested that their incidence may have accelerated, at least temporarily, the retreat of the Sefströmbreen ice cliffs. Each spell included periods of spring tides, the first associated with the full moon on $3^{\circ}$ July, the second accompanying the new moon on 15 August. Moreover, the highest daily readings ( 1 , O I 4 and 1 , O $15 \mathrm{mb}$.) coincided with these lunar phases. Consequently they were marked by very low tides. At low-water springs on ${ }_{5} 5$ August some scores of metres of the red silt-covered and normally wholly submerged off-shore zone were exposed. A spate of very active calving from the ice cliffs of Sefströmbreen and from those of Sveabreen, farther down the fjord, was observed to follow the times of low sea-level and would seem to have been induced by it. Particularly rigorous calving "spasms" appeared to take place at or very shortly after the turn of low tide.

The observations which form the basis of these notes were made while the writers were members of the Birmingham and Exeter Universities Spitsbergen Expedition. Grateful acknowledgement is made of the financial assistance that was provided by the Universities of Birmingham and Exeter and by the Royal Geographical Society to make the expedition possible. Thanks are also due to many commercial firms for their generous assistance to the expedition and to Norsk Polarinstitutt for photographs and unpublished information.

MS. received I Fanuary 1960 


\section{R E F E R E N G E S}

I. Geer, G. de. Guide de l'excursion au Spitzberg. Stockholm, XI Congrès Géologique International, Igro.

2. Lamplugh, G. W. The shelly moraine of the Sefström Glacier. Proceedings of the Yorkshire Geological Society, Vol. I7, I911, p. 222

3. Lamplugh, G. W. op. cit., p. 224.

4. Gripp, K. Glaciologische und geologische Ergebnisse der Hamburgischen Spitzbergen-Expedition I927. Abhandlungen aus dem Gebiete der Naturwissenschaften hrsg. vom Naturwissenschaftlichen Verein in Hamburg, Vol. 22,
I929, p. $184-85$.

5. Lamplugh, G. W. op. cit., p. 22 r.

6. Lamplugh, G. W. op. cit., p. 221.

7. Ahlmann, H. W:son. Glaciological research on the North Atlantic coasts. London, Royal Geographical Society, I 948, p. 66. (R.G.S. Research Series, No. I.)

8. Glen, J. W. Experiments on the deformation of ice. Journal of Glaciology, Vol. 2, No. 12, 1952, p. I I I-14. 